\title{
Survey of indigenous natural enemies of the adventive pest Thrips palmi (Thysanoptera: Thripidae) on the Ryukyu Islands, Japan
}

\author{
Yoshimi Hirose, Yoshitaka Nakashima, Masami Takagi, Kazuya Nagai, ${ }^{1}$ Katsuya Shima, \\ Keiji Yasuda $^{2}$ and Katsuyuki Kohno ${ }^{3}$ \\ Institute of Biological Control, Faculty of Agriculture, Kyushu University, Fukuoka 812-8581, Japan \\ ${ }^{1}$ Okayama Prefectural Agricultural Experiment Station, Okayama 709-0801, Japan \\ ${ }^{2}$ Okinawa Prefectural Agricultural Experiment Station, Naha, Okinawa 903-0814, Japan \\ ${ }^{3}$ Okinawa Subtropical Station, Japan International Research Center for Agricultural Sciences, Ishigaki, Okinawa 907- \\ 0002 , Japan
}

(Received 10 May 1999; Accepted 18 June 1999)

\begin{abstract}
Natural enemies of Thrips palmi were surveyed on Okinawa and Ishigaki Islands of the Ryukyu Islands, to identify potentially effective, indigenous natural enemies against this adventive pest. A number of predators were found: Piocoris varius, Orius tantillus and $O$. strigicollis were collected on Okinawa Island, while $P$. varius, $O$. tantillus and Campylomma chinensis were collected on Ishigaki Island. Of these indigenous predators, $P$. varius is most likely to be effective against $T$. palmi in wax gourd gardens on Okinawa Island. Outbreaks of $T$. palmi were found just after its accidental introduction into the Ryukyu Islands in 1980, but there have been no serious outbreaks on the islands since several years after the introduction. Our study indicates that the indigenous complex of natural enemies may play a key role in suppressing T. palmi populations in southern Japan. Potential use of the generalist predators on the Ryukyu Islands for the biological control of greenhouse pests under short-day conditions in more northern temperate regions is also suggested.
\end{abstract}

Key words: Thrips palmi, Orius spp., Piocoris varius, adventive pest, indigenous generalist predators

\section{INTRODUCTION}

Thrips palmi Karny has been an important pest of vegetables, such as cucumber, eggplant, watermelon, muskmelon and green pepper in Japan since its discovery in Kyushu in 1978. However, this adventive pest can be naturally suppressed by indigenous generalist predators, such as Orius sauteri (Poppius), O. minutus L. and $O$. nagaii Yasunaga on eggplant in Honshu and Kyushu if selective pesticides are applied to the pest (Nagai, 1991, 1993; Ohno et al., 1995). In addition, Ceranisus menes (Walker), an indigenous parasitoid of thrips, is effective against T. palmi when found with Orius spp. in Kyushu (Hirose et al., 1992). These results suggest the importance of indigenous natural enemies in $T$. palmi suppression, and indicate the need for an intensive survey of indigenous natural enemies of $T$. palmi in Japan. Thus, we conducted a survey to identify natural enemies of $T$. palmi on Okinawa Island during 1994-1998 and on
Ishigaki Island in 1998. Both islands belong to the Ryukyu Islands extending in a $1,300 \mathrm{~km}$ long arc between Kyushu and Taiwan. Okinawa Island is the largest of the Ryukyu Islands situated in the subtropical region of Japan.

Since the invasion of Kyushu by T. palmi, this pest has extended its range to Shikoku, Honshu and the Ryukyu Islands in Japan. On the Ryukyu Islands, T. palmi was discovered in 1980 in a watermelon greenhouse in Okinawa City on Okinawa Island (Suzuki and Miyara, 1984a). Damage from this pest was found on other islands including Ishigaki Island on the Ryukyu Islands in 1981-1982 (Miyazaki, 1988). On Okinawa Island, T. palmi is also an important vector of tomato spotted wilt virus which has been injurious to cucurbits including cucumber, wax gourd and watermelon since 1982 (Hokama and Tokashiki, 1986, 1987). Thus, the invasion of Okinawa Island by $T$. palmi caused more serious problems than that of the Japanese mainland. Damage to vegeta- 
bles by $T$. palmi over several years after the initial invasion had been so enormous that the integration of physical control and chemical control of this pest was intensively investigated on different vegetables on Okinawa Island (Suzuki et al., 1982, 1986; Suzuki and Miyara, 1983, 1984a, b; Kinjo et al., 1985; Suzuki and Miyagi, 1987). However, no studies have been conducted on the biological control of T. palmi on this island.

This paper reports the results of our survey and discusses which T. palmi indigenous natural enemies are effective, indigenous natural enemies of $T$. palmi on the Ryukyu Islands. Throughout the paper, the term "Japanese mainland" refers to the temperate area consisting of Kyushu, Shikoku and the southern part of Honshu where T. palmi is distributed.

\section{METHODS}

Our survey was conducted eight times during 1994-1998 on Okinawa Island and once in 1998 on Ishigaki Island. On Okinawa Island, only the southern regions, which covered Haebaru-cho, Kochinda-cho, Gushikami-son, Ohzato-son, Tamagusuku-son, Tomigusuku-son, and Itoman City, were surveyed. The eight surveys were conducted as follows: 1: Aug. 3-4, 1994; 2: Oct. 6-7, 1994; 3: Dec. 12-14, 1994; 4: Apr. 26-27, 1995; 5: Aug. 2-3, 1995; 6: Oct. 15, 1996; 7: Aug. 12-13, 1997; 8: July 29-30, 1998.

During the 1st, 4th, 5th, 7th and 8th surveys, wax gourd was selected as one of the target crops because this crop is commonly cultivated on Okinawa Island and is often left unsprayed with insecticides during the harvest season from end July to early August. The numbers of wax gourd gardens examined during the 1st, 4th, 5th, 7 th and 8th surveys were 7, 12, 18, 5 and 7 , respectively. With the exception of two gardens in the 4th survey, all gardens were located in the field.

Eggplant gardens were also surveyed. The numbers of eggplant gardens examined during the lst, 3rd, 4th, 5th, 7th and 8th surveys were 2 , $7,2,6,4$ and 1 , respectively. In contrast to wax gourd gardens, eggplant gardens were often located in greenhouses.

Presence-absence sampling (Wilson et al., 1983; Zalom et al., 1984) was used to deter- mine the abundance of $T$. palmi and hemipteran predators in each of the gardens. Thirty buds and 30 leaves were randomly sampled from wax gourd and eggplant, respectively, in each garden for each survey, and the proportions of buds and leaves with $T$. palmi larvae and adults, and with nymphs and adults of hemipteran predators were recorded. To determine the percentage parasitism of $T$. palmi larvae, 10-30 2nd stadium larvae of $T$. palmi were collected from each wax gourd and eggplant garden and dissected in the laboratory. In some gardens less than 10 2nd stadium larvae of $T$. palmi were dissected due to low numbers of larvae.

During the 2nd and 6th surveys, collections were made for Orius in grasses and herbs inhabited by thrips in several uncultivated sites in Kochinda-cho and Gushikami-son because wax gourd and eggplant gardens on Okinawa Island are rarely found in October. Sweep net samples were obtained from 10 sweeps at each site.

On Ishigaki Island, our survey was made in the southern and eastern regions during July $27-28,1998$. In addition to 8 wax gourd gardens and 2 eggplant gardens, 5 pumpkin gardens were also examined. The same sampling method used on Okinawa Island was applied to buds of wax gourd and pumpkin and to leaves of eggplant.

\section{RESULTS}

\section{Predators}

We identified the following four predators as natural enemies of T. palmi in our survey.

1. Piocoris varius (Uhler) (Hemiptera: Lygaeidae)

Although this species was known to be distributed on both the Ryukyu Islands and the Japanese mainland (Yasunaga et al., 1993), it has never been recorded as a predator of $T$. palmi in Japan. We often observed $P$. varius preying on $T$. palmi in wax gourd gardens on Okinawa Island. We also observed predation in the laboratory, using $P$. varius adults collected from wax gourd gardens on Okinawa Island and laboratory-reared T. palmi larvae as prey. One adult of $P$. varius was observed to feed on at least $302 \mathrm{nd}$ stadium larvae of $T$. palmi per day.

On Okinawa Island, P. varius was common 
in wax gourd gardens which were not sprayed with insecticides in mid summer of 1994, 1995, 1997 and 1998 (Table 1). T. palmi larvae and adults were abundant during the summer season in all of the four years surveyed (Table 1), occurring in a total of 26 nonsprayed gardens during the four years. Throughout our survey on Okinawa Island, no $P$. varius were found in four wax gourd gardens sprayed with insecticides, nor in any of the eggplant gardens examined. However, about $64 \%$ of the eggplant gardens were sprayed with insecticides.

On Ishigaki Island, $P$. varius were found in one of the six unsprayed pumpkin gardens, and the frequency of occurrence in this garden was as low as 0.03 . No $P$. varius occurred in unsprayed wax gourd gardens on this island (Table 2).

2. Orius tantillus (Motschulsky) (Hemiptera: Anthocoridae)

On Okinawa Island, this species was rare in wax gourd gardens unsprayed with insecticides; it was found in only one garden in 1994 and not found in any gardens for the other three years (Table 1). Although eggplant gardens were not common, and unsprayed eggplant gardens were even less common, $O$. tantillus was found in only one of the nine unsprayed eggplant gardens surveyed during the four year period. The frequency of occurrence in this garden was as low as 0.03 .

$O$. tantillus was abundant in some grasses and herbs on Okinawa Island. In an unsprayed garden of wax gourd in Yoza, Gushikami-son on Aug. 4, 1994, T. palmi was present, but $O$. tantillus was absent, while about 30 adults of this predator were collected from grasses (i.e., Setaria Faberi Herrmann, S. viridis (L.), and Digitaria ciliaris (Retz.) Koeler) adjacent to the garden. Because these grasses were inhabited by many thrips species other than T. palmi, $O$. tantillus probably preyed on these thrips. Adults and nymphs of $O$. tantillus were also abundant in a 15 a area consisting of rose grass Chloris gaiana Kunth which was surrounded by sugar cane fields in Ohton, Gushikami-son, on Oct. 6, 1994. Ears of this grass harbored many thrips species other than $T$. palmi which were probably prey for $O$. tantillus. From the grass, 2-8 O. tantillus were collected by 10 sweeps, and

Table 1. Numbers of T. palmi and its natural enemies, $P$. varius and $O$. tantillus, collected in pesticide-free wax gourd gardens in mid summer of 1994, 1995, 1997, and 1998 on Okinawa Island

\begin{tabular}{lcccc}
\hline \multirow{2}{*}{ Survey date } & \multirow{2}{*}{$\begin{array}{c}\text { No. of gardens } \\
\text { examined }\end{array}$} & \multicolumn{2}{c}{ Mean frequency of occurrence ${ }^{\mathrm{a}}$} \\
\cline { 3 - 5 } & & T. palmi & P. varius & O. tantillus \\
\hline Aug. 3-4, 1994 & 6 & 0.67 & 0.07 & 0.01 \\
Aug. 2-3, 1995 & 8 & 0.71 & 0.01 & 0 \\
Aug. 12-13, 1997 & 5 & 0.54 & 0.09 & 0 \\
July 29-30, 1998 & 7 & 0.69 & 0.04 & 0 \\
\hline
\end{tabular}

${ }^{\text {a }}$ Mean proportion of buds with at least one larva (nymph in the case of $P$. varius and $O$. tantillus) or one adult of $T$. palmi and its natural enemies per bud to all buds (usually 30 buds) sampled in each garden.

Table 2. Numbers of T. palmi and its natural enemies, $P$. varius, O. tantillus and $C$. chinensis, collected in pesticide-free wax gourd or pumpkin gardens on Ishigaki Island on July 27-28, 1998

\begin{tabular}{lccccc}
\hline \multirow{2}{*}{ Vegetable } & $\begin{array}{c}\text { No. of gardens } \\
\text { examined }\end{array}$ & \multicolumn{4}{c}{ Mean frequency of occurrence } \\
\cline { 3 - 6 } & & $T$. palmi & P. varius & O. tantillus & C. chinensis \\
\hline Wax gourd & 6 & 0.81 & 0 & 0 & 0.01 \\
Pumpkin & 5 & 0.62 & 0.01 & 0.02 & 0.02 \\
\hline
\end{tabular}

${ }^{\mathrm{a}}$ See Table 1. 
a total of 400 adults and nymphs was collected by sweeping during $3 \mathrm{~h}$. About 100 adults of $O$. tantillus were again collected from the grass in Ohton on December 14, 1996. On October 16, 1996, ca. 100 and ca. 80 adults and nymphs of this species were collected from grasses and $\mathrm{Bi}$ dens pilosa L. at two sites in Kochinda-cho.

On Ishigaki Island, O. tantillus was found in one of the six pumpkin gardens which were not sprayed with insecticides. The frequency of occurrence in this garden was 0.09 , suggesting that it is more commonly found in pumpkin gardens than in wax guard gardens. In six unsprayed gardens of wax gourd, no $O$. tantillus was found (Table 2).

3. Orius strigicollis (Poppius) (Hemiptera: Anthocoridae)

Three adults of this species were collected together with adults of $O$. tantillus from rose grass in Ohton, Gushikami-son, on December 14, 1994. O. strigicollis was found neither on eggplant nor on wax gourd on Okinawa Island. This species was not found on Ishigaki Island.

4. Campylomma chinensis Schuh (Hemiptera: Miridae)

This species was found in both types of wax gourd and pumpkin gardens on Ishigaki Island, but its abundance was not very high in either type of field (Table 2). C. chinensis was not found on Okinawa Island.

\section{Parasitoids}

No eggs or larvae of the parasitoid $C$. menes were found on Okinawa Island in spite of collections totaling 140 2nd stadium larvae of $T$. palmi in wax gourd and eggplant gardens unsprayed with insecticides.

\section{DISCUSSION}

Based on the results of the present survey and literature records, Table 3 lists the species of natural enemies of $T$. palmi on the Ryukyu Islands and the Japanese mainland.

The two predators, $O$. tantillus and Franklinothrips vespiformis (Crawford), were not found on the Japanese mainland, but only on the Ryukyu Islands because the ranges of these two species are restricted to tropical to subtropical regions (Yasunaga, 1997; Arakaki and Okajima, 1998). As a predator of T. palmi,
$O$. tantillus is known to be common in the Philippines (Bernardo, 1989) and was also recorded from Thailand (Yasunaga and Miyamoto, 1993). $F$. vespiformis was reported to be a predator of T. palmi in Thailand (Hirose et al., 1993). This species was probably introduced into Okinawa Island in 1996 (Arakaki and Okajima, 1998).

$O$. sauteri, $O$. minutus and $O$. nagaii are not found on the Ryukyu Islands because they are temperate species (Yasunaga, 1997). Wang and Chen (1993) recorded $O$. sauteri as a predator of T. palmi from Taiwan, and Wang (1995) reported the predatory capacity of this predator on T. palmi in Taiwan. Yasunaga (personal communication), however, identified Wang's specimens as $O$. strigicollis.

On both the Ryukyu Islands and the Japanese mainland, $P$. varius is common (Miyamoto, personal communication), but it has never been recorded as a predator of $T$. palmi from the Japanese mainland. On Okinawa Island, $P$. varius was common in wax gourd gardens which are rarely found on the Japanese mainland. $P$. varius is known to be a generalist predator; it attacks various insects, such as scales, ants, leaf beetles, drosophilas and carpet beetles (Yasunaga et al., 1993).

According to Wang (1995), C. chinensis is most commonly found on $T$. plami-infested eggplant and cucurbit in Taiwan, together with $O$. strigicollis (referred to as $O$. sauteri). The predatory capacity of $C$. chinensis exceeded that of $O$. strigicollis in a laboratory study (Wang, 1995). C. chinensis is distributed on the Ryukyu Islands, Kyushu, and Shikoku (Yasunaga et al., 1993). However, this species does not seem to be an effective natural enemy of $T$. palmi on the Ryukyu Islands because of low densities.

Sakimura (1937) reported rearing $C$. menes from Thrips tabaci Lindeman collected on Okinawa Island, Ishigaki Island (he wrote Yaeyama Island, but it is actually Ishigaki Island), and Miyako Island in 1933. However, this parasitoid was not found in the present survey. The reason for this remains unknown. C. menes is a cosmopolitan species (Bouček, 1988), and has been recorded as a parasitoid of T. palmi and other thrips on the Japanese mainland (Murai, 1989; Hirose et al., 1992), 
Taiwan (Chang, 1990), and Thailand (Hirose et al., 1993).

On both the Ryukyu Islands and the Japanese mainland, effective natural enemies of T. palmi were indigenous generalist predators (Table 3). In wax gourd gardens which were not sprayed with insecticides on Okinawa Island, T. palmi occurred in mid summer in all four years sur-

Table 3. Natural enemies of $T$. palmi recorded from the Ryukyu Islands and the Japanese mainland. Asterisks indicate that the records are based only on literature on distribution of the species.

\begin{tabular}{|c|c|c|}
\hline \multirow{2}{*}{$\begin{array}{l}\text { Order and family of predators } \\
\text { and parasitoids of } T . \text { palmi }\end{array}$} & \multicolumn{2}{|c|}{ Species of parasitoids or predators of $T$. palmi. } \\
\hline & The Ryukyu Islands & The Japanese mainland \\
\hline \multicolumn{3}{|l|}{ Predators: } \\
\hline \multicolumn{3}{|l|}{ Hemiptera } \\
\hline \multicolumn{3}{|l|}{ Anthocoridae } \\
\hline & Orius tantillus $\mathrm{s}^{\mathrm{a}}$ & \\
\hline & O. strigicollis ${ }^{\mathrm{a}}$ & O. strigicollis ${ }^{\mathrm{b}}$ \\
\hline & & O. sauteri \\
\hline & & O. minutus ${ }^{\mathrm{d}}$ \\
\hline & & O. $n a g a i i^{\mathrm{d}}$ \\
\hline \multicolumn{3}{|l|}{ Berytidae } \\
\hline & & Yemma exilis $^{\mathrm{e}}$ \\
\hline \multicolumn{3}{|l|}{ Lygaeidae } \\
\hline & Piocoris varius ${ }^{\mathrm{a}}$ & P. varius $^{* \mathrm{f}}$ \\
\hline \multicolumn{3}{|l|}{ Miridae } \\
\hline & Campylomma chinensis ${ }^{\mathrm{a}}$ & C. chinensis $^{\mathrm{f}}$ \\
\hline \multicolumn{3}{|l|}{ Coleoptera } \\
\hline \multicolumn{3}{|l|}{ Coccinellidae } \\
\hline & Propylea japonica ${ }^{* g}$ & P. japonica ${ }^{\mathrm{c}}$ \\
\hline \multicolumn{3}{|l|}{ Thysanoptera } \\
\hline \multicolumn{3}{|l|}{ Thripidae } \\
\hline & Franklinothrips vespiform & \\
\hline \multicolumn{3}{|l|}{ Acarina } \\
\hline \multicolumn{3}{|l|}{ Phytoseiidae } \\
\hline & Amblyseius okinawanus $^{* \mathrm{i}}$ & A. okinawanus ${ }^{\mathrm{j}}$ \\
\hline & A. longispinosus ${ }^{* i}$ & A. longispinosus ${ }^{\mathrm{j}}$ \\
\hline & & A. tsugawal \\
\hline \multicolumn{3}{|l|}{ Erythraeidae } \\
\hline & & Unknown genus sp. ${ }^{c}$ \\
\hline \multicolumn{3}{|l|}{ Parasitoids: } \\
\hline \multicolumn{3}{|l|}{ Hymenoptera } \\
\hline \multicolumn{3}{|l|}{ Eulophidae } \\
\hline & Ceranisus menes $^{\mathrm{k}}$ & C. menes \\
\hline
\end{tabular}

${ }^{a}$ Recorded in the present survey.

${ }^{\mathrm{b}}$ Takai (1998).

${ }^{\mathrm{c}}$ Nagai (1993).

${ }^{\mathrm{d}}$ Ohno and Takemoto (1997).

${ }^{\mathrm{e}}$ Kohno and Hirose (1997).

${ }^{f}$ Yasunaga et al. (1993).

${ }^{\mathrm{g}}$ Sasaji (1985).

${ }^{\text {h }}$ Arakaki and Okajima (1998).

${ }^{\mathrm{i}}$ Ehara (1980).

${ }^{j}$ Kajita (1985).

${ }^{\mathrm{k}}$ Sakimura (1937).

${ }^{1}$ Hirose et al. (1992). 
veyed. It is evident, however, that $T$. palmi densities were lower following several years after the invasion of Okinawa Island because $T$. palmi outbreaks have not occurred over the past ten years (Yasuda, personal observation). Although chemical and cultural control measures for $T$. palmi have been intensively proposed for several years since its invasion of the Ryukyu Islands, practical application measures have been made primarily in greenhouses (Yasuda, personal observation). Thus, these measures could not contribute to the reduction of $T$. palmi in the field. With respect to wax gourd gardens on Okinawa Island, $P$. varius may be an effective natural enemy which contributes to the reduction of $T$. palmi in the field. On the Japanese mainland, generalist predators, such as $O$. sauteri, $O$. minutus, and $O$. nagaii are effective against $T$. palmi in eggplant gardens (Nagai, 1991, 1993; Ohno et al., 1995). On Kyushu and the Ryukyu Islands, infestation areas of $T$. palmi increased rapidly during the first several years after the invasion by this pest. The proportion of severe infestation areas to the infestation areas reached ca. 50\% a few years after the invasion, but gradually decreased to 20-30\% by seven or eight years (Kawai, 1990). This supports the view that T. palmi has been suppressed since several years ago on both the Ryukyu Islands and the Japanese mainland. We suggest that indigenous generalist predators play an important role in such suppression of $T$. palmi.

Walker (1994) reviewed the natural enemies of $T$. palmi occurring throughout the world. From her review, it is clear that there are limited records on indigenous natural enemies of this pest from Hawaii, Trinidad, and China in which $T$. palmi is established. In Darwin and its vicinity in Australia, however, it is suggested that $T$. palmi is suppressed by its indigenous natural enemies if pesticides are used to conserve them. In this area, E. S. C. Smith (personal communication) observed a marked reduction of $T$. palmi populations three or four years after the invasion by this pest. Later, Young and Zhang (1998) recorded many indigenous natural enemies, such as Delaeocoris sp., a predatory mite, a predatory thrips and a lacewing from this area, reporting that
Delaeocoris sp. is the most important natural enemy of $T$. palmi. This mirid predator plays a major role in suppressing T. palmi in the Darwin area if insecticidal soaps are used on the crop (Young and Zhang, 1998; Young, personal communication). Thus, intensive surveys of indigenous natural enemies of T. palmi should be conducted in many different areas invaded by this pest throughout the world because such an adventive pest could be naturally suppressed by indigenous predators.

Surveys of indigenous natural enemies of $T$. palmi in the subtropical region of the Ryukyu Islands are useful for finding non-diapausing natural enemies which can be used in the biological control of greenhouse pests during winter. Use of non-diapausing natural enemy species or strains can solve the problem of inactivity of diapausing natural enemies as biological control agents under short-day conditions (Meiracker, 1994; Nakashima and Hirose, 1997). Of the natural enemies found in the present survey, only $O$. tantillus was reported to be a non-diapausing species (Nakashima and Hirose, 1997). Whether or not the other species are non-diapausing remains to be determined, but the determination of such a property should be made for $P$. varius in particular because of its effectiveness as a natural enemy of T. palmi.

\section{ACKNOWLEDGEMENTS}

We thank Dr. J.Y. Honda for reviewing the manuscript. We also thank Dr. T. Yasunaga for identifying the predatory bugs, and along with Dr. S. Miyamoto, for providing useful information on these bugs. Thanks are due to Messrs. N. Tamaki, Y. Nagamine, H. Soemori, A. Goya and Y. Sadoyama, Dr. H. Nakamori and Mrs. K. Kinjo for their help in conducting our survey. We are grateful to Messrs. E.S.C. Smith and G. Young for providing valuable information on T. palmi and its natural enemies in Northern Australia.

\section{REFERENCES}

Arakaki, N. and S. Okajima (1998) Notes on the biology and morphology of a predatory thrips, Franklinothrips vespiformis (Crawford) (Thysanoptera: Aeolothripidae): first record from Japan. Entomol. Sci. 1: 359-363.

Bernardo, E. N. (1989) Thrips on vegetable crops in the Philippines. In Thrips in Southeast Asia (N.S. Talekar ed.). AVRDC, Taipei, pp. 5-11.

Bouček, Z. (1988) Australian Chalcidoidea (Hymenoptera). $\mathrm{C} \cdot \mathrm{A} \cdot \mathrm{B}$ International, Wallingford. $832 \mathrm{pp}$. 
Chang, N.T. (1990) Ceranisus menes (Walker) (Eulophidae: Hymenoptera), a new parasite of bean flower thrips, Megalurothrips usitatus (Bagnall) (Thripidae: Thysanoptera). Pl. Prot. Bull. 32: 237-238.

Ehara, S. (1980) Phytoseiidae. In Illustrations of the Mites and Ticks of Japan (S. Ehara ed.). Zenkoku Noson Kyoiku Kyokai, Tokyo, pp. 52-67 (in Japanese).

Hirose, Y., H. Kajita, M. Takagi, S. Okajima, B. Napompeth and S. Burnapanichpan (1993) Natural enemies of Thrips palmi and their effectiveness in the native habitat, Thailand. Biol. Control 3: 1-5.

Hirose, Y., M. Takagi and H. Kajita (1992) Discovery of an indigenous parasitoid of Thrips palmi Karny (Thysanoptera: Thripidae) in Japan: Ceranisus menes (Walker) (Hymenoptera: Eulophidae) on eggplant in home and truck gardens. Appl. Entomol. Zool. 27: 465-467.

Hokama, K. and I. Tokashiki (1986) Control of wax gourd virus disease caused by tomato spotted wilt virus by physical methods. Proc. Assoc. Pl. Prot. Kyushu 32: 45-48 (in Japanese).

Hokama, K. and I. Tokashiki (1987) Yield loss of cucumber infected with tomato spotted wilt virus. Proc. Assoc. Pl. Prot. Kyushu 33: 39-41 (in Japanese with English summary).

Kajita, H. (1985) Predatory natural enemies of Thrips palmi. Pulex No. 71: 329-330 (in Japanese).

Kawai, A. (1990) Techniques for pest control: Thrips palmi. In Development of Agricultural Techniques in Kyushu Region. Kyushu Nogyokenkyushikenkenkyukikan Kyogikai, Chikugo, pp. 197-199 (in Japanese).

Kinjo, T., T. Nakasono, M. Arasaki, Y. Nagamine, H. Suzuki and A. Miyara (1985) Integrated control of Thrips palmi on green pepper cultivated in a greenhouse. Proc. Assoc. Pl. Prot. Kyushu 31: 160-165 (in Japanese).

Kohno, K. and Y. Hirose (1997) The stilt bug Yemma exilis (Heteroptera: Berytidae) as a predator of Aphis gossypii (Homoptera: Aphididae) and Thrips palmi (Thysanoptera: Thripidae) on eggplant. Appl. Entomol. Zool. 32: 406-409.

Meiracker, R. A. F. van den (1994) Induction and termination of diapause in Orius predatory bugs. Entomol. Exp. Appl. 73: 127-137.

Miyazaki, M. (1988) Taxonomic revision, occurrence and distribution of Thrips palmi and its allied species. In Studies on the Control of Thrips palmi (Res. Council Secretariat, Min. Agr. For. ed.). Res. Council Secretariat, Min. Agric. For., Tokyo, pp. 6-13 (in Japanese).

Murai, T. (1989) Ecology of thrips. Insectarium 26: 348-353 (in Japanese).

Nagai, K. (1991) Integrated control programs for Thrips palmi Karny on eggplant (Solanum melongena L.) in an open field. Jpn. J. Appl. Entomol. Zool. 35: 283-289 (in Japanese with English summary).

Nagai, K. (1993) Studies on integrated pest management of Thrips palmi Karny. Spec. Bull. Okayama Pref. Agric. Exp. Stn. No. 82: 1-55 (in Japanese with English summary).

Nakashima, Y. and Y. Hirose (1997) Winter reproduction and photoperiodic effects on diapause induction of Orius tantillus (Motschulsky) (Heteroptera: Anthocoridae), a predator of Thrips palmi. Appl. Entomol. Zool. 32: 403-405.

Ohno, K. and H. Takemoto (1997) Species composition and seasonal occurrence of Orius spp. (Heteroptera: Anthocoridae), predacious natural enemies of Thrips palmi (Thysanoptera: Thripidae), in eggplant fields and surrounding habitats. Appl. Entomol. Zool. 32: 27-35.

Ohno, K., H. Takemoto, K. Kawano and K. Hayashi (1995)
Effectiveness of integrated pest control program for Thrips palmi Karny on eggplant: a case study in a commercial field. Bull. Fukuoka Agric. Res. Cent. No. 14: 104-109 (in Japanese with English summary).

Sakimura, K. (1937) On the bionomics of Thripoctenus brui Vuillet, a parasite of Thrips tabaci Lind., in Japan (I). Kontyû 11: 370-390.

Sasaji, H. (1985) Coccinellidae. In Colored Illustrations of the Coleoptera of Japan. Vol. III (Y. Kurosawa, S. Hisamatsu and H. Sasaji eds.). Hoikusha, Osaka, pp. 245-270 (in Japanese).

Suzuki, H., S. Hanashiro, F. Nakasone, S. Yamauchi and A. Miyara (1986) Integrated control of Thrips palmi on cucumber (watermelon and waxgourd) fields. Proc. Assoc. Pl. Prot. Kyushu 32: 158-162 (in Japanese).

Suzuki, H. and S. Miyagi (1987) Integrated control of Thrips palmi on eggplant cultivation in a greenhouse and field. Proc. Assoc. Pl. Prot. Kyushu 33: 154-158 (in Japanese).

Suzuki, H. and A. Miyara (1983) Integrated control of Thrips palmi using silver-colored materials. (1) Loss assessment on cucumber. Proc. Assoc. Pl. Prot. Kyushu 29: 77-80 (in Japanese).

Suzuki, H. and A. Miyara (1984a) Studies on ecology and control of the southern yellow thrips, Thrips palmi Karny (Thysanoptera: Thripidae). (1) Physical control using agricultural covering materials. Bull. Okinawa Agric. Exp. Stn. No. 9: 85-93 (in Japanese with English summary).

Suzuki, H. and A. Miyara (1984b) Integrated control of Thrips palmi using agricultural covering materials. Proc. Assoc. Pl. Prot. Kyushu 30: 135-139 (in Japanese).

Suzuki, H., S. Tamaki and A. Miyara (1982) Physical control of Thrips palmi Karny. Proc. Assoc. Pl. Prot. Kyushu 28: 134137 (in Japanese).

Takai, M. (1998) Control of insect pests on eggplant using indigenous natural enemies in an open field I. Seasonal trend of the major insect pests of eggplant and their natural enemies. Bull. Kochi Agric. Res. Cent. 7: 21-27 (in Japanese with English summary).

Walker, A.K. (1994) A review of the pest status and natural enemies of Thrips palmi. Biocontrol News Inform. 15: 7N$10 \mathrm{~N}$.

Wang, C. L. (1995) Predatory capacity of Campylomma chinensis Schuh (Hemiptera: Miridae) and Orius sauteri (Poppius) (Hemiptera: Anthocoridae) on Thrips palmi. In Thrips Biology and Management (B. L. Parker, M. Skinner and T. Lewis eds.). Plenum Press, New York, pp. 259-262.

Wang, C.L. and W.S. Chen (1993) Control of Thrips palmi Karny (Thysanoptera: Terebrantia). Plant Prot. Soc. Rep. China, Spec. Publ. New Ser. No. 1: 183-195 (in Chinese with English summary).

Wilson, L. T., C. Pickel, R. C. Mount and F. G. Zalom (1983) Presence-absence sequential sampling for cabbage aphid and green peach aphid (Homoptera: Aphididae) on brussels sprouts. J. Econ. Entomol. 76: 476-479.

Yasunaga, T. (1997) The flower bug genus Orius Wolff (Heteroptera: Anthocoridae) from Japan and Taiwan, Part III. Appl. Entomol. Zool. 32: 387-394.

Yasunaga, T. and S. Miyamoto (1993) Three anthocorid species (Heteroptera: Anthocoridae), predators of Thrips palmi (Thysanoptera) in eggplant gardens of Thailand. Appl. Entomol. Zool. 28: 227-232.

Yasunaga, T., M. Takai, I. Yamashita, M. Kawamura and T. Kawasawa (1993) A Field Guide to Japanese Bugs. Terrestrial Heteropterans (M. Tomokuni ed.). Zenkoku Noson Kyoiku 
Kyokai, Tokyo, 380 pp. (in Japanese).

Young, G. and L. Zhang (1998) Control of the melon thrips, Thrips palmi. Agnote No. 753: 1-3.

Zalom, F. G., M. A. Hoy, L. T. Wilson and W. W. Barnett (1984)
Sampling mites in almonds II. Presence-absence sequential sampling for Tetranychus mites species. Hilgardia 52(7): 1424. 